\title{
Information on Impacts of Climate Change and Adaptation in China
}

\author{
X. J. He* \\ The Administrative Center for China's Agenda 21, Beijing 100038, China
}

Received 8 March 2016; revised 16 January 2017; accepted 20 January 2017; published online 29 June 2017

\begin{abstract}
Climate change adaptation in China faces dual challenges: the development demand and its increasing pressure. In recent years, China has made great efforts in climate change impact assessment, adaptation policy-making, as well as technological research and development. The objective of this paper is to analyze and summarize the achievements and gaps of improving the adaptation strategies. A case study focusing on China is provided as a reference for other developing countries. In China, positive and negative impacts coexist, with the negatives outweighing the positives. Climate change affects mainly seven fields, including agriculture, water resources, coastal zone, ecosystem and biodiversity, urban development, major projects, and human health. A top-down policy system of climate change adaptation in China consists of 117 national and departmental policies, 31 provincial action plans and 21 provincial adaptation plans. There is an increasing number of climate change adaptation policies appearing in China. Identification, classification and key-chain analysis are performed over the adaptation policies, in order to build up the technology system that captures their structure and characteristics. Progress has been made in the development and application of the top 10 adaptation technologies, such as extreme weather event prediction and early warning technology, integrated adaptation technology for human health, as well as technology for the conservation and restoration of typical climate-sensitive ecosystems. However, gaps still exist in the mismatch between adaptation goals and resource management in terms of adaptation policy-making, adaptation mechanism of global changes, and strategic adaptation technology and top-level design.
\end{abstract}

Keywords: climate change impacts, adaptation policy, adaptation science and technology, Chinese characteristics

\section{Introduction}

Climate change has been closely related to the rise and fall of a civilization such as ten major disasters throughout ancient Egyptian history, the glory of the Great Tang Dynasty in China, the disappearance of ancient Kroraina and the decline of the Mayan civilization. According to five assessment reports on climate change, several special reports on adaptation by the Intergovernmental Panel on Climate Change (IPCC, 1990a; 1990b; 1995; 1997; 2001; 2007; 2012; 2014), and three "National Assessment Reports on Climate Change" in China (NARCC EC, 2007; 2011; 2015), global warming is an indisputable fact. Climate change has led to frequent droughts, floods, water shortages and imbalances in water distribution, as well as reduced biodiversity. In addition, ecological security is at risk, which posese major challenges to the sustainable development of the economy and society around the world (Huang et al., 2006; Li et al., 2008b; Li et al., 2009; Qin et al., 2007; Lv et al., 2010). Adaptation to climate change has become an inevitable choice for the collective needs of society. As the impacts become increasingly preva-

${ }^{*}$ Corresponding author. Tel.: +86 13466621685; fax: +86 1058884860 .

E-mail address: hexiaojia@acca21.org.cn (X. J. He).

ISSN: 1726-2135 print/1684-8799 online

(C) 2017 ISEIS All rights reserved. doi: 10.3808/jei.201700367 lent, it is difficult for the developed countries to avoid serious harm posed by such impacts, even if they have strong ability in climate change adaptation. Many countries are showing increasing focus on climate change adaptation (Biesbroek et al., 2010) to move to low carbon economy.

As one of two important strategies for reducing the impacts of climate change, the other being mitigation strategy, adaptation is an urgent task for China (MOST and ACCA21, 2012; ACCA21, 2017). China, with its large population, complex climatic conditions, fragile ecological environment, and frequent extreme weather events, is one of the countries that is seriously affected by climate change. China is also one of the several developing countries with significant development in industrialization, informatization, urbanization and agricultural modernization. To protect food security, ecological security, human lives, property, and scientific achievements, China should prioritize adaptation to climate change. If no effective measure is taken, losses will increase, which may hinder further development of China's economy and society (NARCC EC, 2015). "The 13th Five-Year Plan for Economic and Social Development of the People's Republic of China” outlines the need for enhanced climate change adaptation. President Xi Jinping made a declaration at the Paris climate conference of paying equal attention to adaptation and mitigation of climate change. The signing of the Paris agreement announced China's intention to build a "climate adaptation" society (Li et al., 2014; UNFCCC, 2015; Chen et al., 2016). 
China attaches great importance to global leadership in climate change adaptation. China takes the first place among developing countries to develop Agenda 21, exercises initiatives from the United Nations Framework Convention on Climate Change, establishes a national leadership and coordination mechanism on climate change, and developes a series of major policies and actions. China also funds research and technology development in climate change adaptation. Since the "11th Five-Year Plan" period, the Ministry of Science and Technology and 14 other ministries and commissions have jointly launched China's Scientific and Technological Actions on Climate Change, accelerated basic and key technology research and development, built technologically integrated applications and carried out international technological cooperation on climate change adaptation, which have yielded remarkable results.

This paper summarizes the results from climate change impact assessments, adaptation policy design, technological research and development, as well as the gaps in adaptation progress and the proposed strategic recommendations for future climate change adaptation for China. This study also seeks to extend the basis of adaptation strategy in China through a case study, which may benefit other developing countries. The paper is organized as follows: section 2 summarizes climate change impacts in seven fields and divides the impacts into positive and negative ones; section 3 summarizes adaptation policy progress at the national and regional levels and analyzes adaptation policy development; section 4 summarizes the results and achievements of adaptation science and technologies, including the framework of adaptation technologies, as well as its associated progress and applications; section 5 discusses China's adaptation characteristics, the adaptation principle of "seeking advantages and avoiding disadvantages”, the gaps, and recommentations for adaptation policy, science and technology; section 6 presents the conclusions of this study.

\section{Climate Change Impacts in China}

According to the latest instrumental records on temperature time series from the past century, the average land warming in China between 1909 and 2011 is in the range of 0.9-1.5 ${ }^{\circ} \mathrm{C}$ (NARCC EC, 2015), higher than the global average. Climate warming leads to the observed patterns of water, heat resources and environmental factors, resulting in both direct and indirect impacts on natural ecosystems, as well as China's socio-economic development. Vulnerable fields affected by climate change in China are as follows: agriculture, water resources, coastal zones, ecosystems and biodiversity, urban development, major projects, and human health. The overall and specific climate impacts in each field are summarized in Table 1.

Some climate change impacts may be conducive to the environment and socio-economic development. Global warming can lead to an increase in thermal resources in agriculture, which aids in the expansion of arable land in the north (Shi et al., 2002; Lian et al., 2007). The amount of precipitation increases significantly in the western region (Zhang et al., 2007). As a result, the net primary productivity of vegetation increased in Xinjiang and Tibet (Zhang et al., 2007). For the current climate of China, a slight increase in temperature is beneficial to forest ecosystems which are mainly carbon sinks.

There are also negative impacts. Climate warming leads to a serious shortage of water resources and the uneven distribution, resulting in augmented instability of agricultural production (Sun et al., 2010). Corn and wheat production in northeast China is greatly affected (Tao et al., 2012). Because of a significant increase in temperature and a decrease in precipitation, the vegetation coverage in the permafrost area decreases largely (Mao et al., 2011). The net primary productivity decreases in the ecotone between agriculture and animal husbandry in northern China (Liu et al., 2009; Li et al., 2012). The frequency and intensity of extreme weather events increases significantly in most areas throughout China (Zhang et al., 2008). Mangrove and coral reef ecosystems degrad severely (Hu et al., 2008; Shi et al., 2008). Climate change poses negative influence on the richness and diversity of species, such as some species' extinction from their original habitats (Ma et al., 2006; Yuan et al., 2007). Changes in the distribution of harmful organisms excerts increased risk in causing habitat degradation (Zhao et al., 2007; Li et al., 2008a). More and more cities in China experiences an increase in the frequency of extreme precipitation events (Chen et al., 2010). Climate change causes high temperature heat waves and other extreme weather events that affect human health (Qian et al., 2010), such as the increasing risk of infectious diseases (Lu et al., 2010; Yang et al., 2010a; Yang et al., 2010b) and the expanding scope of vector borne diseases (Zhou et al.,2007). Climate change has significant negative impacts on many projects (Dai et al., 2007; Ren et al., 2008; Ren, 2012). In summary, positive and negative impacts of climate change coexist, but the negatives outweigh the positives (Wu et al., 2014).

\section{Adaptation Policies in China}

\subsection{Programs for Adaptation Policies}

According to the results of the "Third National Assessment Report on Climate Change in China" (NARCC EC, 2015), a top-down policy system of climate change adaptation formed after the State Council issued the "National Program on Climate Change” in 2007, which included 117 national and departmental level policies, 31 provincial action plans and 21 provincial adaptation plans. In Figure 1, the first level is named as "Top level design", which includes the aforementioned "National Program on Climate Change" in 2007, and the new "National Program on Climate Change (2014-2020)". Both documents outline China's overall framework for action on climate change, including climate adaption. The second level is "National action". This includes the "National strategy of climate change adaptation”, as well as relevant laws and regulations guiding the formulation and implementation of adaptation policies in China. The bottom level is composed of 
Table 1. Climate Change Impacts in China (NARCC EC, 2015)

\begin{tabular}{|c|c|c|}
\hline Fields & Overall impacts & Specific impacts \\
\hline Agriculture & $\begin{array}{l}\text { Expansion of the sown area of medium- and } \\
\text { late-ripening crops; unit yield loss and quali- } \\
\text { ty decline of some crops; degradation of farm } \\
\text { land quality; increased cost of fertilizers and } \\
\text { water; aggravated agricultural disasters. }\end{array}$ & $\begin{array}{l}\text { Unit yields of wheat, maize and soybean from } 1980 \text { to } 2008 \text { drop by } \\
1.27 \%, 1.73 \% \text { and } 0.41 \% \text { respectively, while the unit yield of rice in- } \\
\text { crease by } 0.56 \% \text {; if the annual temperature rises by } 1{ }^{\circ} \mathrm{C} \text {, crop areas } \\
\text { affected by the pest risks in China will increase by } 96 \text { million hm², and } \\
\text { the release period of available nitrogen will be reduced by } 3.6 \text { days; the } \\
\text { target on grain self-sufficiency in China is forced to be lowered by } \\
0.4 \% \text { from } 95 \% \text {. }\end{array}$ \\
\hline $\begin{array}{l}\text { Water } \\
\text { Resources }\end{array}$ & $\begin{array}{l}\text { The measured runoffs of major rivers in } \\
\text { China have reduced. Under RCP4.5, the total } \\
\text { water resource will decrease by less than } 5 \% \\
\text { in the future. Climate change will intensify } \\
\text { the frequency and magnitude of rainstorms, } \\
\text { storm surges, large-scale droughts and other } \\
\text { extreme weather events. }\end{array}$ & $\begin{array}{l}\text { Runoff of Haihe River Basin has diminished by } 40-60 \% \text {, and the mid- } \\
\text { dle and lower reaches of the Yellow River also experience such a re- } \\
\text { duction by } 30-60 \% \text {. The contribution rate of climate change is } 26 \% \text { for } \\
\text { Haihe River, } 38 \% \text { for Yellow River, and } 30 \% \text { for Liaohe River. } \\
\text { Droughts-affected area of Haihe River Basin has been increasing by } \\
3.18 \% \text { every ten years. For the last } 60 \text { years, } 16 \text { provinces suffered } \\
\text { severe droughts in consecutive years. }\end{array}$ \\
\hline Coastal Zone & $\begin{array}{l}\text { Coastal sea level rises; storm surges, aggra- } \\
\text { vated ocean acidification, severe and wide } \\
\text { coastal erosion, coastal wetland loss, degra- } \\
\text { dation of ecosystems such as mangroves and } \\
\text { coral reefs, and fisheries and offshore aqua- } \\
\text { culture. }\end{array}$ & $\begin{array}{l}\text { During the period } 1980 \text { to } 2012 \text {, coastal sea level rose by } 2.9 \mathrm{~mm} / \text { year, } \\
\text { a rate higher than the global average. From } 1986 \text { to } 1996 \text {, the average } \\
\text { reduction in the area of the Yellow River Delta was } 26 \mathrm{~km}^{2} / \mathrm{a} \text {; since the } \\
1980 \text { s, Guangdong has seen a loss of more than } 50 \% \text { of its coastal wet- } \\
\text { lands; the coastal coral coverage in the mainland and the Hainan Island } \\
\text { has plummeted by more than } 80 \% \text { in the last } 30 \text { years; the mangrove } \\
\text { area has plunged by } 73 \% \text {. }\end{array}$ \\
\hline $\begin{array}{l}\text { Ecosystem and } \\
\text { Biodiversity }\end{array}$ & $\begin{array}{l}\text { Ecosystems have largely benefited from } \\
\text { climate change but there are also many ad- } \\
\text { verse impacts. In the future, the impacts of } \\
\text { climate change will be mostly negative, but } \\
\text { there will be no irreversible impacts on ter- } \\
\text { restrial ecosystems if temperature increase } \\
\text { being below } 3{ }^{\circ} \mathrm{C} \text {. }\end{array}$ & $\begin{array}{l}\text { Carbon sinks of forests increase } 51.0 \mathrm{TgC} / \mathrm{a} \text { from } 1984 \text { to } 2003 \text {; NPP is } \\
\text { likely to rise by } 10-20 \% \text { in the } 2030 \text { s and } 28-37 \% \text { in the } 2090 \mathrm{~s} \text {; The } \\
\text { Wetland area in the Poyang Lake in } 2000 \text { was about } 11 \% \text { less than that } \\
\text { in the 1990s; in the future, the elevation of alpine pasture grasslands in } \\
\text { the Qinghai-Tibet Plateau, Tianshan Mountains, and Qilian Mountains } \\
\text { will grow by } 380-600 \text { m. There will also be changes in animal distribu- } \\
\text { tion, phenology and migration, which are caused by the reduction in the } \\
\text { area of habitat, degradation of habitat quality, and changes in wintering } \\
\text { habitats. }\end{array}$ \\
\hline $\begin{array}{l}\text { Urban } \\
\text { Development }\end{array}$ & $\begin{array}{l}\text { Urban inundation; disrupted transportation, } \\
\text { infrastructure. , and people's life appear. }\end{array}$ & $\begin{array}{l}\text { From } 2008 \text { to 2010, } 62 \% \text { of the cities in China suffered inundation and } \\
137 \text { cities experienced frequent inundation. }\end{array}$ \\
\hline Major Project & $\begin{array}{l}\text { South-North Water Diversion Project's mid- } \\
\text { dle route, Three Gorges Project, Qing- } \\
\text { hai-Tibet Railway, and Three-North Shelter- } \\
\text { belt Project have been affected. The associ- } \\
\text { ated adverse impacts will increase in the } \\
\text { future. }\end{array}$ & $\begin{array}{l}\text { The actual annual mean runoff received in the Danjiangkou Reservoir } \\
\text { was } 18.5 \% \text {, less than that of the planed capacity; annual precipitation } \\
\text { will increase by } 6.1-9.7 \% / 100 \text { a in Three Gorges Project region; annual } \\
\text { temperature of above }-0.5^{\circ} \mathrm{C} \text { will cause the Qinghai-Tibet Railway to } \\
\text { moving downward by } 30 \mathrm{~cm} \text { in } 50 \text { years. }\end{array}$ \\
\hline Human Health & $\begin{array}{l}\text { Climate change has lead to climate related } \\
\text { diseases and mortality. }\end{array}$ & $\begin{array}{l}\text { Northward-shift of endemic area of vector-borne diseases; accelerated } \\
\text { spread of infectious diseases. Higher frequency and intensity of heat } \\
\text { waves and extreme events lead to an increase in mortality caused by } \\
\text { certain diseases. }\end{array}$ \\
\hline
\end{tabular}

*Overall and specific climate impacts in table are summarized from the Chapter 2 in "National Assessment Report of Climate Change (III)".

a series of specific policy measures and actions developed by departments and local governments according to different divisions of labor and their characteristics, which will be incorporated into the socio-economic and ecological civilization construction (Peng et al., 2015).

One hundred and nineteen climate change adaptation policies can be analyzed from issued departments, categories and dates. The policies are issued by 13 national departments including the Ministries of Science and Technology, Water Resources, Agriculture, and Environmental Protection. The more the areas under the department's jurisdiction are affected by climate change, the more policies are issued. From an adaptation point of view, the policies can be divided into regulations, strategies and planning. One hundred and nineteen poli- cies include 59 plans (accounting for about 50\%), 28 strategies (accounting for about 24\%), and 32 regulations (accounting for about 26\%). From the time of release, 2009-2011 was the period in which the volume of climate change policies reached at its peak, with $72 \%$ being adaptation policies.

Thirty-one provinces (including autonomous regions and municipalities) in China made local climate change plans in 2009 and started to implement the plans, according to the “National Program on Climate Change” requirements. In 2011, the National Development and Reform Commission issued the "Guidelines for the formulation of local climate change planning” for the local governments. Recently, Beijing, Shanghai, Tianjin, and a total of 23 provinces such as Jiangxi, Shaanxi (including autonomous regions) issued provincial 
plans to respond to climate change. Some provinces also actively promoted the development of local laws and regulations in order to standardize the actions, tasks, and safeguards addressing climate change. Moreover, Qinghai and Shanxi provinces issued corresponding measures to deal with climate change. Although there is no specific climate change adaptation policy in these two provincies, adaptation-related content is included in local climate change planning, laws and regulations.

\subsection{Tendency of Adaptation Policies}

Currently in China, there is only a few policies focusing on climate change adaptation (Table 2). Industries and other sectors closely related to climate change impacts are given more consideration to the need of climate change adaptation. There is an increasing trend in the number of climate change adaptation policies in China, indicating that the interconnections between climate policies and relevant policy areas to mainstream climate change concerns are strenghthening (Kok and Coninck, 2007). The special climate change adaptation policies, together with the government's mainstreaming policies, constitute the basis of climate change adaptation issue in China (Zhang et al., 2015).

The special adaptation policies constitute the core of China's climate change adaptation policy system and outline a top-level design. Since 2007, the Chinese government has formulated and issued only about 10 policies focusing on cli- mate change adaptation (Table 2). Although other policies such as "National Program on Climate Change" and "Science and Technology Special Actions Addressing Climate Change in China" include climate change mitigation strategies, the "National Strategy for Climate Adaptation" and "Action plan for urban adaptation to climate change" are completely independent. Climate change adaptation is indicated in special chapters and content in the files. The objectives, basic principles, key areas and measures are clearly defined in the special adaptation policies. The work of the State Council and its constituent departments should be coordinated and deployed from the perspective of climate change adaptation. Taking "National Climate Change Science and Technology Development Plan” in "12th Five-Year Plan” as an example. This plan guides China's climate change science and technology actions. Key adaptation areas should focus on water resources, agriculture, forestry, marine, human health, ecological system, major projects, disaster prevention and many others. Mechanisms and evaluation methods for the impacts of climate change should be improved. The theoretical and technical research and development capabilities should be enhanced. The adaptation technologies demonstrated in typical fragile regions and areas should be carried out. In particular, the top ten key adaptation technologies are screened out and emphasized in the plan. According to the plan, the Ministry of Science and Technology deployed a series of research projects to adapt to climate change in the "12th Five-Year Plan". The "National Climate Change Science and Technology Devel-

Table 2. Special Climate Change Adaptation Policies (Zhang et al., 2015)

\begin{tabular}{|c|c|c|c|c|}
\hline $\begin{array}{l}\text { Released } \\
\text { department }\end{array}$ & Name & Time & Adaptation content & Reference \\
\hline State Council & $\begin{array}{l}\text { National Program on Climate } \\
\text { Change }\end{array}$ & 2007 & $\begin{array}{l}\text { Objectives, basic principles, key areas and } \\
\text { measures before } 2010\end{array}$ & (State Council,2007) \\
\hline NDRC & $\begin{array}{l}\text { National Strategy for Climate } \\
\text { Adaptation }\end{array}$ & 2013 & $\begin{array}{l}\text { Special climate Adaptation Strategy on nati- } \\
\text { onal level }\end{array}$ & (NDRC, 2013) \\
\hline NDRC & $\begin{array}{l}\text { National Program on Climate } \\
\text { Change (2014-2020) }\end{array}$ & 2014 & $\begin{array}{l}\text { Objectives, policies, key tasks and safegu- } \\
\text { ards during 2014-2020 }\end{array}$ & (NDRC, 2014) \\
\hline NDRC & $\begin{array}{l}\text { Interim Measures for the adminis- } \\
\text { tration of foreign cooperation in the } \\
\text { field of climate change }\end{array}$ & 2010 & $\begin{array}{l}\text { Strengthening the management of foreign } \\
\text { cooperation }\end{array}$ & (NDRC, 2013) \\
\hline MOST & $\begin{array}{l}\text { China's Science and Technology } \\
\text { Actions on Climate Change }\end{array}$ & 2007 & $\begin{array}{l}\text { Implement National Program on Climate } \\
\text { Change in science and technology area }\end{array}$ & (MOST, 2007) \\
\hline MOST & $\begin{array}{l}\text { National Climate Change Science } \\
\text { and technology development plan } \\
\text { in the 12th Five-Year Plan }\end{array}$ & 2012 & $\begin{array}{l}\text { Guides for science and technology actions in } \\
\text { the 12th Five-Year Plan }\end{array}$ & (MOST, 2012) \\
\hline $\begin{array}{l}\text { Forestry } \\
\text { Administration }\end{array}$ & $\begin{array}{l}\text { Forestry action to address climate } \\
\text { change in the } 12 \text { th Five-Year Plan }\end{array}$ & 2011 & $\begin{array}{l}\text { Implement National Program on Climate } \\
\text { Change in forest area }\end{array}$ & $\begin{array}{l}\text { (Forestry Administra- } \\
\text { tion, 2011) }\end{array}$ \\
\hline $\begin{array}{l}\text { Meteorological } \\
\text { Administration }\end{array}$ & $\begin{array}{l}\text { Action Plan for implementing } \mathrm{Na}- \\
\text { tional Program on Climate Change }\end{array}$ & 2007 & $\begin{array}{l}\text { Implement National Program on Climate } \\
\text { Change in meteorological area }\end{array}$ & $\begin{array}{l}\text { (Meteorological Ad- } \\
\text { ministration, 2007) }\end{array}$ \\
\hline $\begin{array}{l}\text { Oceanic } \\
\text { Administration }\end{array}$ & $\begin{array}{l}\text { Oceanic Program on Climate } \\
\text { Change }\end{array}$ & 2009 & $\begin{array}{l}\text { Implement National Program on Climate } \\
\text { Change in Oceanic area }\end{array}$ & $\begin{array}{l}\text { (Oceanic Administra- } \\
\text { tion, 2009) }\end{array}$ \\
\hline $\begin{array}{l}\text { NDRC\& MO- } \\
\text { HURD }\end{array}$ & $\begin{array}{l}\text { Action plan for urban adaptation to } \\
\text { climate change }\end{array}$ & 2016 & $\begin{array}{l}\text { Implement National Strategy for Climate } \\
\text { Adaptation; enhance the ability of cities to } \\
\text { adapt to climate change }\end{array}$ & $\begin{array}{l}\text { NDRC\& MOHURD, } \\
2016\end{array}$ \\
\hline
\end{tabular}

*NDRC means National Development and Reform Commission, MOST means Ministry of Science and Technology, MOHURD means Ministry of Housing and Urban-Rural Development of the People's Republic of China. 
opment Plan” in “13th Five-Year Plan” will be released later in 2017.

In concert with special climate change adaptation policies, mainstreaming policies can improve the adaption ability of various fields (e.g., ecological and environmental protection, disaster prevention and mitigation, health insurance, urban development, and so on). The "National Comprehensive Disaster Prevention and Mitigation Plan (2011-2015)" focuses on strengthening the construction of risk management policies in natural disaster, including frequent disasters caused by climate change (State Council, 2011). "China’s Biodiversity Conservation Strategy and Action Plan (2011-2030)” outlines further requirements to strengthen China's biodiversity conservation, especially under climate change (MEP, 20 10). The requirements of "National Environment and Health Action Plan (2007-2015)" are designed to strengthen the efforts in the legislation, management and technology fields regarding the environment and health, through controling heath-related negative effects of climate change, such as reducing the occurrence of climate related diseases and maintainning public health (MOHC, 2007). "Guidelines of the National Committee for Disaster Reduction” points out that strengthening the comprehensive disaster reduction in urban and rural areas is an important part of climate change adaptation requirements (NCDR, 2011).

\section{Adaptation Sciences and Technologies}

\subsection{Framework of Climate Change Adaptation Technologies}

The adaptation technology system can be divided into three parts: climate change impacts and risk assessment, adap- tation technology, and adaptation mechanisms. Speicially, adaptation technology includes natural and human system adaptation technologies. The technology sub-system can generate several adaptation technology systems for different fields, industries, and regions (Figure 1) (ACCA21, 2017).

The criterion for identifying climate change adaptation technology are one component within the methodology for climate change adaptation. Identification is the first step to $\mathrm{cr}-$ eate a framework. The core criteria for identification originates from the pertinence of climate change problems. How to distinguish the adaptation aspect from routine aspects of technologies? According to the Fifth Assessment Report of IPCC, the first principle of effective adaptation is to adapt to climate change, reduce risk and consider the dynamic changes of vulnerability and exposure. Also, adaptation and mitigation technologies are different. It is important to discriminate between mitigation and adaptation effects. According to the aforementioned criteria, the existing adaptation technologies in different regions and fields can be recognized and selected (Li et al., 2015).

Classification of climate change adaptation technologies can 1) provide a foundation for the selection, integration, and benefit assessment of adaptation technologies, and 2) establish a solid basis for the framework of climate change adaptation technology system. Different classification patterns for adaptation technologies can be summarized according to the process of climate change, regions, sectors, purpose, mechanism, timeliness, degree, level, etc. The adaptation technologies can be classified into 3 categories based on the process of climate change, such as before, during, and after climate change. Based on regions and sectors, adaptation technologies can be classified into 8 regions (Northeast, Northwest, South-

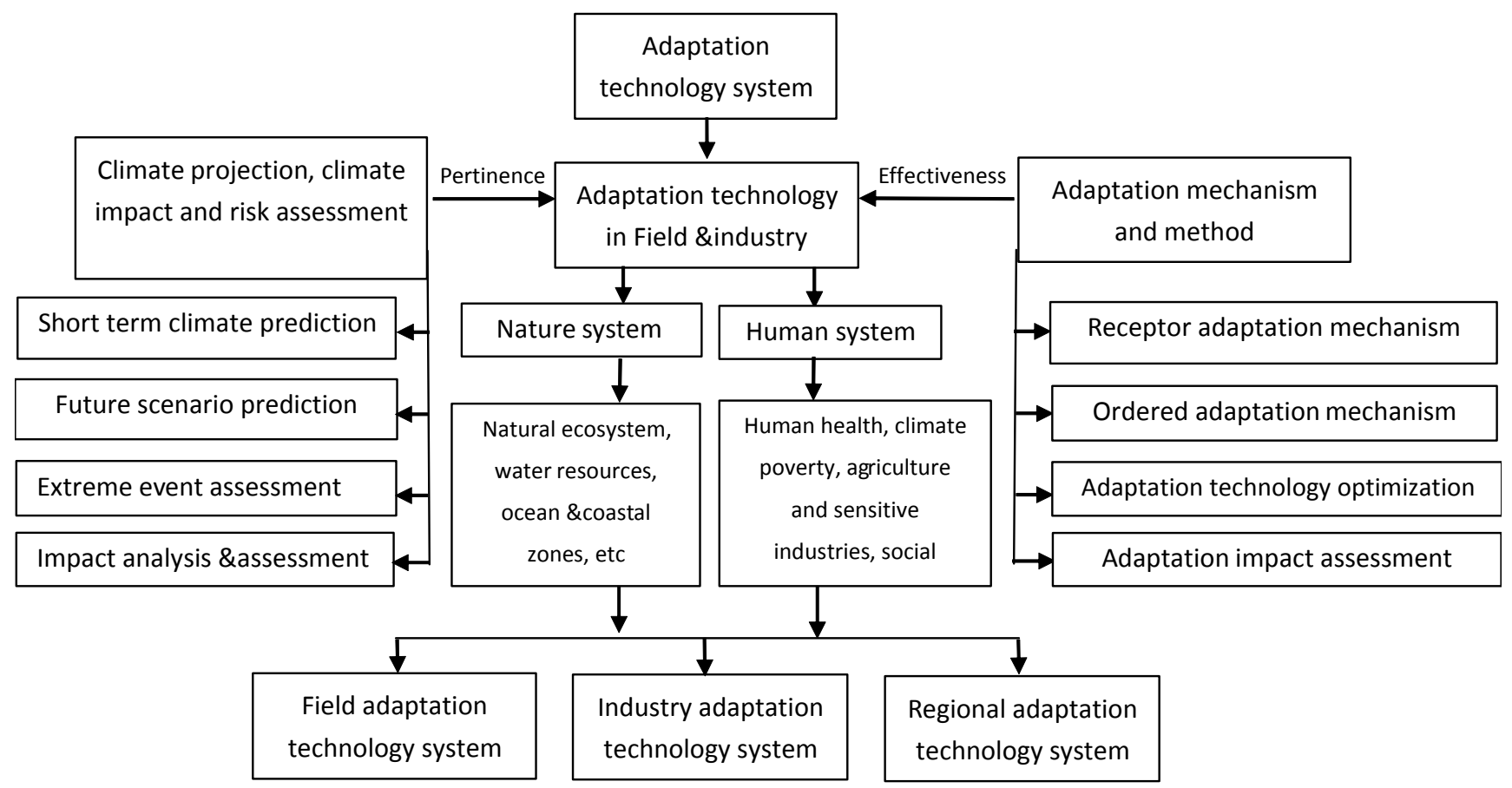

Figure 1. Framework of climate change adaptation technologies. 
east, and Southwest of China, etc.) and 7 sectors (agriculture, water resource, and ecology environment, etc.) ( $\mathrm{Li}$ et al., 2016).

Sorting the chain of climate change adaptation technologies is a part of the theoretical guidance for building the framework of a climate change adaptation technology system. Using technology prediction and selection as a basis for the adaptation of a technology chain for climate change adaptation starts with the need for climate change adaptation in China. Issues such as guidance are raised, strengthening the effectiveness of and assessment links for climate change adaptation technology. Three key links make up the technology chain for climate change adaptation: climate prediction technology, climate impact and risk assessment technology, as well as climate change adaptation technology (Figure 1). Accurate climate change projections are selected with adaptation evidence and objects. It is beneficial to bridge the gap between the impact of climate change and adaptation technology, which can improve the relevance of adaptation technology (Mastrandrea et al., 2010; ACCA21, 2017).

The technology list for climate change adaptation is a concrete composition of the framework for climate change adaptation technology system. The technology list factors include the impact of climate change and vulnerability in the field, the choice of appropriate countermeasures and measures to adaptation cost and benefit evaluation, as well as the selection, demonstration and promotion of adaptation technology (Smit, 1993; Ju et al., 2010; Margul et al., 2010; Peng and Lu, 2012). Numerous patents on climate change adaptation technologies are available upon request from a patent examination information inquiry (Liu et al., 2013). The technology list for climate change adaptation can be prepared for different areas. Agriculture, forest, water, coastal belt, ecosystem and human health are considered as research topics which are predisposed to climate change. Eleven expressions of adaptation technology are selected, such as early warning, engineering, dynamic monitoring, evaluation, disaster prevention, adaptation space, longacting adaptation, model analysis, and major engineering technologies. Industry standards, specifications and social influence as well as public opinion are additional expressions of adaptation technology (Ge et al., 2015).

\subsection{Progress in the Development of Adaptation Technologies}

The top ten adaptation technologies are emphasized in the "National Climate Change Science and Technology Development Plan in 12th Five-Year” (Table 3). Progress has been made in the development and application of these ten adaptation technologies. The technologies aim to solve severe climate change problems in adaptation, such as extreme weather events, water resource shortages, crop diseases and insect pests, biodiversity conservation, rising sea levels, etc. Different adaptation technologies are adopted in different sectors and regions according to local characteristics and the severity of climate change impacts. The technologies are ap- plied to sectors such as meteorology, agriculture, water conservancy, human health, and urban development. Vulnerable areas of climate change are involved in applied regions, such as the Qinghai-Tibet Plateau, arid regions, coastal zones, Yellow River basin, Yangtze River basin, and urban areas in China.

\section{Discussions}

\subsection{Adaptation Characteristics}

China's adaptation to the impacts of climate change is facing the challenges of the development demand and its increasing pressure. The strategic position of adaptation in addressing climate change and the development of the country should be improved. Climate change adaptation in China has its own characteristics, which can be described as dual challenges. The challenge comes from the lack of adaptation to the impacts of climate change caused by lower socio-economic development. In addition, the challenge also comes from the lack of adaptation to climate change in the future. As a developing country, China's national conditions and developmental stage demonstrate that China is facing not only a need to enhance sustainable development, but also the increasing adaptaion needs associated with the projected climate change risk. The "development" adaptation refers to coping with the risks of climate change as well as social and economic development at the same time, given the lack of investment and ability to build in adaptation due to development lag. The "increasing" adaptation deals with the new climate risk adaptation when the basic needs are satisfied (Pan et al., 2011).

Therefore, the strategic position of adaptation in addressing climate change and the country's development should be improved, by taking its "Chinese characteristics” into account. China's adaptation to climate change must consider economic development and climate protection within its sustainable development framework. One may adjust the mode of development to adapt to the changing climate, and achieve a win-win situation between social and economic development and climate change. In the relatively developed regions of China, one should focus on the increased climate change risks, in addition to coping with existing risks, especially in densely populated coastal areas. In the developing regions of China, one can compensate insufficient investment of existing risk and consider new risks, such as climate poverty in ecologically fragile areas. This requires adaptation to climate change with poverty alleviation while identifying its vulnerable population and priorities in its adaptation. Integrating climate change adaptation into regional socio-economic development plans, and in particular in less developed regions, helps to achieve the national goal of eliminating absolute poverty by 2020 .

\subsection{Principle of "Seeking Advantages and Avoiding Disadvantages”}

The impacts of climate change can be positive and 
Table 3. Progress in the Development and Application of Ten Adaptation Technologies (NARCC EC, 2015)

\begin{tabular}{|c|c|}
\hline Technology & Development Progress \\
\hline
\end{tabular}

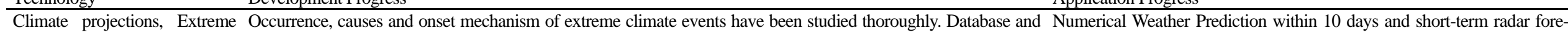

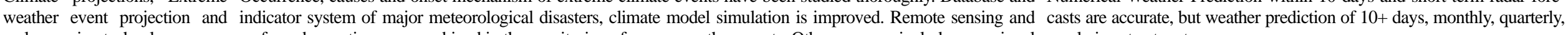
early warning technology surface observations are combined in the monitoring of severe weather events. Other progress includes: a regional yearly is not yet mature. climate model (RegCM4.0) (Gao et al., 2013); dynamical-statistical downscaling approach by coupling the PRECIS regional modelling system (Wang et al., 2015); high-resolution probabilistic projections of temperature changes (Wang et al., 2014); statistical downscaling and dynamical downscaling (Tang et al, 2016); multi-model ensembles for regional climate downscaling (Reichler et al., 2016).

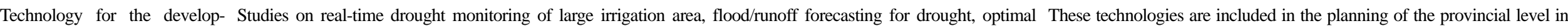

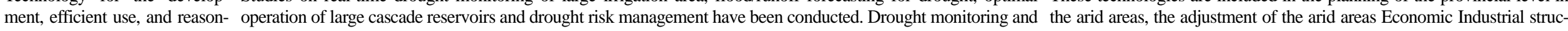

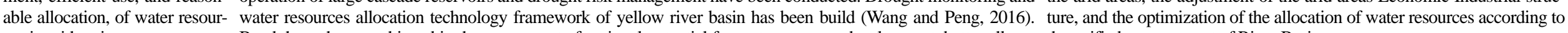
ces in arid regions Breakthroughs are achieved in the assessment of regional potential for water resource development, better alloca- the unified management of River Basin. tion of water resources in river basins, under-mulch drip irrigation (Wu et al., 2016).

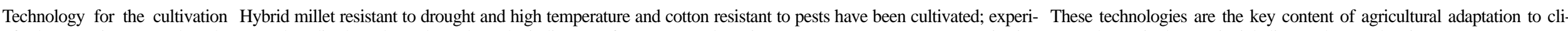
of plants resistant to drought mental studies have been done about the indicators of crop pests' adaptation to extreme temperatures; a projection mate change in the provincial climate change planning. and high temperature and pest model has been developed about the long-term trends in pest occurrence in the context of global warming- proand disease control

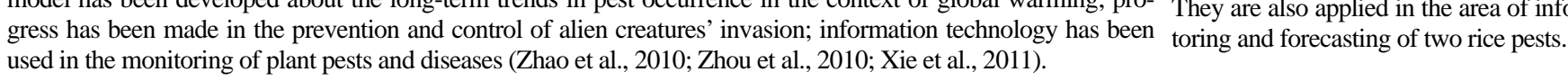

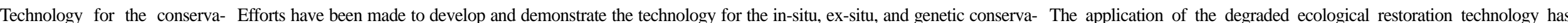

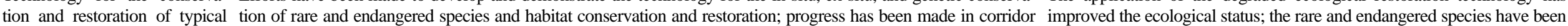
climate-sensitive ecosystems construction for the migration of endangered species; Degradation causes and loading capacity of semi-arid effectively protected and the habitat has been improved. Applications also grasslands have been assessed and a plan has been carried out to achieve forage-livestock balance; the technology include ecological protection planning (Feng and Li, 2016) for restoring degraded ecosystem has been developed and demonstrated; the list of endangered plants and animals have been worked out and priority regions selected (Wu et al., 2011).

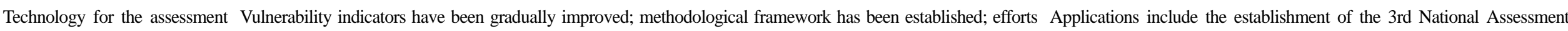
of climate change impacts and have been made to develop technology for risk assessment taking into account social and economic factors; ex- Report in China. risks plorations have been made on adaptation priorities.

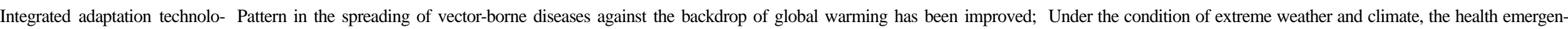
gy for human health Monitoring and assessment of climate change's impacts on human health and the research into the habits of vectors has been studied. plan has been gradually improved, and the establishment of the early warning system has made the number of casualties caused by extreme weather events largely decrease.

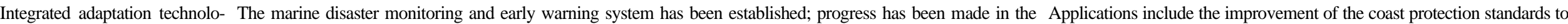
gy for typical coastal zones restoration of coastal ecosystems and the research on the evolution of marine ecosystems; remote sensing has been applied to risk assessment (Zhang, 2010). risk map to promote the rational planning and utilization of the coastal zone, establishment of 19 national marine nature reserves, protected area of more than $1000 \mathrm{~km}^{2}$, regional marine nature reserves of 52, the protection area of more than $1500 \mathrm{~km}^{2}$.

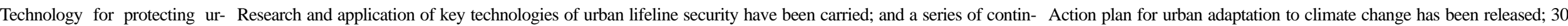
ban lifeline projects in extreme gency plans have been worked out (Song, 2012). weather events

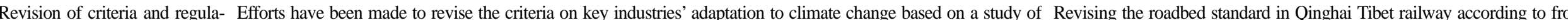

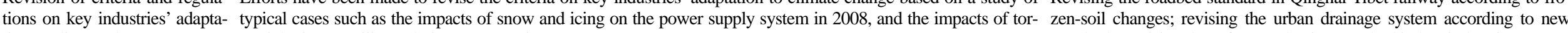
tion to climate change typical cases such as the impacts of snow and icing
rential rain on Beijing's drainage system in 2012. standards; revising the safety production standard in key industries.

Technology for weather modi- Progress has been made in the identification and forecasting of weather good for operations as well as the underfication standing and technology improvement of artificial precipitation stimulation, and hail and fog mitigation.

Artificial rain and snow enhancement and hail suppression technology to alleviate the drought has a large area of application; fog technology is demonstrated in key areas of critical moment. 
negative. "Seeking advantages and avoiding disadvantages" means making full use of opportunities from climate change and avoiding its harmful effects on natural systems and human society. The main principles of adaptation to climate change in China determine how to draw on the advantages and avoid its disadvantages, how to make the best of the favorable factors and opportunities brought by climate change, and how to address various scientific challenges. The existing problems in address various scientific challenges. The existing problems in popularizing this principle include: more focus on avoiding the disadvantages and making use of advantages not fully established. In addition, achieving maximum utilization of resources has not been achieved in practice. The quantification of advantages and disadvantages is insufficient, and targeted measures can not be effectively implemented. Currently, "seeking advantages and avoiding disadvantages" is mainly focused on the field of agriculture.

In regard to global warming impacts, scenarios should make full use of heat resources, longer frostfree periods and other favorable conditions to adjust the planting structure and crop distribution. This leads to changes in cropping systems, improvements in cropping index, development of new crop varieties, and out-of-season vegetables. These measures aim to improve crop yield and guarantee national food safety. At the same time, other resource constraints, such as excessive extraction of groundwater and wetland ecological problems, should be considered in the expansion of the northeast rice species. The balance problem and ecological water planting should be considered for the Xinjiang oasis and Tibet valley area to improve the layout in the valley. Meanwhile, measures need to be taken to avoid disadvantages excerted by climate change on water resources, agriculture, ecosystems and biodiversity, environment, off-shore and coastal zones, major projects, transportation, and regional development. The measures are consistent with national strategy formulation, climate change impact, risk monitoring and evaluation, the development and application of adaptation technology, strengthened financial support, and enhanced public awareness.

\subsection{Adaption Policy}

A mismatch between adaptation goals and resources in adaptation policy-making, as well as the difficulty of evaluation and supervision during policy implementation, still exists. The decision-making mechanism and capacity-building of climate change adaptation policies should be improved. The elements of adaptation policy include four aspects: goal setting, adaptability and resources, decision-making, and implementation. Through the evaluation of the integrity and rationality of the elements in the national and adaptation policies, some problems are found (Peng et al., 2015; Zhang et al., 2015). The adaptation policy goals are clear, but its matching resource of implementation support is insufficient. The importance of human resources and the strengthening of capital investment are mentioned in polices, yet social capital, natural resources and material capital, which are required to achieve the adaptation goals, are not involved. In China, adaptation policy decision-making is based on the opinions of stakeholders and the assessment of climate change impacts. Nevertheless, it is not enough for the evaluation of the nonclimatic factors and future risk assessment. Distribution and promotion channels of adaptation policies are effective and smooth. The implementation results of adaptation policies are obvious. However most adaptation policies do not have a clear description of regulatory mechanisms and effective evaluation work arrangements. There is a disconnection between the perception of risk of climate change and the formulation of adaptation policies. The results of climate change research and the information required for climate change decisions often fail to achieve the "seamless links" requirement (Mastrandrea and Field, 2010).

Adaptation to climate change requires international and national coordination to avoid actions in one region or field damaging efforts from another region or field. Adaptation to climate change needs legislative protection, which requires integrated coordination at the country level, as well as scientific and reasonable planning at the local level. A leading group for climate change adaptation in science and technology should be established with responsibility of top-level design, planning, and coordination of climate change adaptation science and technology at the national level, as well as fully using international, national, regional, departmental, and industrial science and technology resources. It is necessary to enhance the supervision in the process of adaptation policy implication. The "after implementation" policy evaluation system must also be strengthened to ensure the independence of evaluation and seriousness towards the evaluation conclusions. More attention should be paid to the digestion and absorption of the results. Therefore the assessment of the policy can play an essential role. Adaptation to climate change requires improving the matching degree between policy goals and adaptation resources, as well as supporting the necessary human, financial and material resources, to promote future policy implementation.

\subsection{Adaptation Science and Technology}

There remains a gap between "basic science" and "adaptation technology”. Basic and applied research on adaptation to climate change should be strengthened in order to lay a solid foundation for climate change adaptation in China. $\mathrm{Cu}-$ rrently, climate change adaptation actions in China are not sufficiently supported by scientific research. There are still gaps between climate change impact research and adaptation technology. The boundary of climate change adaptation study cannot be clearly distinguished from that of traditional industry or field research. Basic research and technology development of climate change adaptation is still relatively weak. Climate change impacts on water resources, marine environment, biosphere, food safety and human health, as well as its adaptation methodology and routes are not clear enough to support technology development (Huang 1998; Huang and Loucks, 2000; Li et al., 2008c; Li and Huang, 2009; Li et al., 2010). There is a gap in the adaptation mechanism of global 
changes in the climate system and elasticity and threshold of basic research, when comparing with international advanced levels. The adaptation technology system cannot compensate the adverse effects on various fields and industries, especially due to the lack of reserving strategic adaptation technology, including early warning and disaster prevention technology of extreme climate events, the adaptation technology targeting the impacts of climate change on socio-economic development. "Small, scattered, broken" research tasks and nonsymbolic results appear to be with insufficient top-level design. A key challenge is the lack of high-resolution and reliable future climate change scenarios, due to the spatial mismatch in the coarse outputs of global climate models (also known as GCMs) and impact assessment models (such as hydrological and crop models).

Adaptation research that integrates and balances scientific and technological resources, systematically incorporating new advances based on relevant studies in China and all over the world, should be conducted in order to overcome technical bottleneck problems. Special and stable government funding and investment channels, strengthened support to adaptation technology systems, adaptation decision-making, and adaptation propaganda, are needed (Schenkel, 2010). Efforts should be made to enhance empirical, theoretical and comprehensive assessment modeling research based on the mechanism behind the impacts of climate change in all fields, and to assess the impacts of continued global warming scenarios and regional risks. The intention is to further strengthen the links among "climate change-vulnerability-risk-adaptation mechanism-measures", which leads to improvements in the prevalence of adaptation technology. Studies should be carried out on the mechanisms of extreme climate events, the vulnerabilities of every field to climate change, mapping vulnerabilities and general vulnerability distribution, and mapping the risk distribution of climate change. This may improve the study of adaptation in a socio-economic system and advance the adaptability of a non-traditional adaptation field to adapt to climate change. Technologies should be developed to help vulnerable areas to adapt to climate change, particularly those that are highly pertinent. A specific technological system in this field should be built in order to promote integration, application and dissemination of adaptation technologies (ACCA21, 2017).

\section{Conclusions}

Achievements and gaps in climate change impacts and adaptation in China were summarized and analyzed in this study. First, the progress in climate change impact assessment was reviewed from two perspectives of "negative and positive" impacts and "overall and specific" impacts. Then, climate change adaptation information was divided into adaptation policies and adaptation technologies. On one hand, the programs and system of adaptation policies were summarized, with an analysis of the tendency of adaptation policies. On the other hand, the framework of adaptation technologies was built based on identification, classification, and key-chain analysis of a list of adaptation technologies. Results showed that progress has been made in the development and application of the top 10 adaptation technologies. Finally, adaptation characteristics, adaptation principles, gaps and recommendations in adaptation policy and technology were discussed. The main findings were:

1) In China, positive and negative impacts coexist, and the negatives outweigh the positives. Climate change impacts seven main fields, including agriculture, water resources, coastal zone, ecosystems and biodiversity, urban development, major projects, and human health. "Seeking advantages and avoiding disadvantages” is an important principle of climate change adaptation.

2) A top-down policy system of climate change adaptation consists of 117 national and departmental policies, 31 provincial action plans and 21 provincial adaptation plans in China. An obvious mainstream trend of climate change adaptation policies appears in China. Nevertheless, the mismatch between adaptation goals and resources arrangement in adaptation policy-making, and the difficulties of evaluation and supervision during policy implementation, still exist.

3) Identification, classification, and key-chain analysis are performed over a list of climate change adaptation technologies in order to construct a technology system. Progress has been made in the development and application of 10 top adaptation technologies, such as extreme weather event prediction and early warning technology, integrated adaptation technology for human health, as well as technology for the conservation and restoration of typical climate-sensitive ecosystems. However, there are still gaps between climate-impact research and adaptation actions. Gaps remain in adaptation mechanisms for global change, reserving strategic adaptation technology, and top-level design.

4) As a developing country, China has its own climate change adaptation challenges. China is facing dual challengies: the development demand and its increasing pressure. China's adaptation must consider overall economic development and climate protection in a framework of sustainable development.

In the future, the strategic position for adaptation in addressing climate change impacts should be improved, taking its "Chinese characteristics" into account. The "large army fight" in adaptation research should be conducted. Future research directions in this field may include climate change impact assessment quantification, future climate scenario projections, risk assessments under uncertainties, identification of adaptation mechanisms and resilience characteristics of eco-environment systems, and the determination of its threshold and adaptation path. Further research may include mechanism studies in response to typical socio-economic systems under climate changk, which include urban area, village, farmland (e.g., irrigation areas), and commercial forests. There is also a need for methodological studies on climate change adaptation policy decision-making mechanisms, cost benefit analyses, capacity-building of climate change adapta- 
tion policies, integration and optimization of monitoring resources, impact monitoring, and adaptation of data sharing systems.

Acknowledgments. The author would like to thank Yinlong Xu from Institute of Environment and Sustainable Development in Agriculture, Shaohong Wu from Institute of Geographic Sciences and Natural Resources Research, Chinese Academy of Sciences and Weining Xu from Chinese Research Academy of Environmental Sciences for their valuable comments and suggestions.

\section{References}

Biesbroek, G.R., Swart, R.J., and Carter, T.R. et al. (2010). Europe adapts to climate change: Comparing National Adaptation Strategies. Global Environ. Change, 20(3), 440-450. https://doi.org/10. 1016/j.gloenvcha.2010.03.005

Chen, M.P., Zhang, C.Y., Li, B., and Li, Y.E. (2016). Interpretation of adaptation and loss and damage elements in Paris agreement and possible solution for China. Adv. Clim. Change Res., 12(3), 251-257. https://doi.org/10.12006/j.issn.1673-1719.2016.006

Chen, Y., Chen, X.Y., and Ren, G.Y. (2010). Variation of extreme precipitation over large river basins in China. Adv. Clim. Change Res., 6(4), 265-269.

Dai, H.C., Wang, L., and Jiang, D. (2007). Near term water flow and silt concentration variation trend of Yangtze River before and after impounding of Three Gorges Reservoir. J. Hydraul. Eng., 10, 226-231.

Feng, B., and Li, D.Q. (2016). A review of research on terrestrial protected area management in the context of climate change. World For. Res., 29(5), 12-16.

Forestry Administration (2011). Forestry action to address climate change in 12th Five-Year, http://www.gov.cn/gzdt/2012-02/01/ content_2055853.htm

Gao, X.J., Wang, M.L., and Giorgi, F. (2013). Climate change over China in the 21st century as simulated by BCC_CSM1.1RegCM4.0. Atmos. Ocean. Sci. Lett., 6(5):381-386.

Ge, Q.S., Chen, C.Y., Wang, F. et al. (2015). Technical Research and Compilation of Climate Change in Key Areas of China, Meteorological Press, Bejing.

Hu, Y.M., Song, L.J., and Liu, A.J. (2008). The composition of climatic characters for tropical cyclone landfall over different regions in China. Atmos. Sci. Res. Appl., Beijing Science Press, 1, 1-8.

Huang, G.H. (1998). A hybrid inexact-stochastic water management model. Eur. J. Oper. Res., 107(1), 137-158. https://doi.org/10.1016/ S0377-2217(97)00144-6

Huang, G.H., and Loucks, D.P. (2000). An inexact two-stage stochastic programming model for water resources management under uncertainty. Civ. Eng. Environ. Syst., 17(2), 95-118. https://doi.org/ 10.1080/02630250008970277

Huang, G.H., Huang, Y.F., Wang, G.Q., and Xiao, H.N. (2006). Development of a forecasting system for supporting remediation design and process control based on NAPL-biodegradation simulation and stepwise-cluster analysis. Water Resour. Res., 42(6). https://doi.org/10.1029/2005WR004006

IPCC (2012). Managing the Risks of Extreme Events and Disasters to Advance Climate Change Adaptation. Cambridge University Press, Cambridge.

IPCC (1990a). Climate Change: the IPCC Impacts Assessment, Australian Government Publishing Service, Australia.

IPCC (1995). Impacts, Adaptations and Mitigation of Climate Change: Scientific-Technical Analyses, IPCC Working Group II,
Cambridge University Press, Cambridge.

IPCC (1997). The Regional Impacts of Climate Change: An Assessment of Vulnerability, Cambridge University Press, Cambridge.

IPCC(2001). Impacts, Adaptations and Mitigation of Climate Change: Scientific-Technical Analyses, IPCC Working Group II, Cambridge University Press, Cambridge.

IPCC(2007). Climate Change 2007: Impacts, Adaptation, and Vulnerability, Cambridge University Press, Cambridge.

IPCC(2014). Climate Change 2014: Impacts, Adaptation, and Vulnerability, Cambridge University Press, Cambridge.

IPCC(1990b). Climate Change: The IPCC Response Strategies, Australian Government Publishing Service, Australia.

Ju, H., Li, Y.E., and Xu, Y.L. et al. (2010). Action Framework for Climate Change Adaptation. J. Meteorol. Environ., 26(6), 55-58.

Kok, M.T.J, and Coninck, H.C.D. (2007), Widening the scope of policies to address climate change: directions for mainstreaming. Environ. Sci. Policy, 10(7-8), 587-599. https://doi.org/10.1016/j. envsci.2007.07.003

Li, K., and Xu, Y.L. (2015). On critera for identification of adaptation to climate change. Sci. Technol. Rev., 33(16), 95-101.

Li, K., He, X.J., Xu, Y.L., and Zhang, D.W. (2016). Study on classification of adaptation technologies to Climate Change in China. China Popul. Resour. Environ., 26(2), 18-26.

Li, L., Wu S.X., Zhu, X.D., Chang, G.G., and Li, F.X. (2008a). Response of the plateau lakes to changes of climate and frozen earth environment in the headwaters of the Yellow River since the $21 \mathrm{st}$ century. J. Nat. Resour., 23(2), 245-253.

Li, Q.Y., Pan, X.B. (2012). The impact of climate change on boundary shift of farming pasture ecotone in northern China. J. Arid Land Resour. Environ., 26(10), 1-6.

Li, Y., Ma, X., and He, X. (2014). The progress on adaptation negotiations since adoption of Bali Action Plan and future needs analysis. Adv. Clim. Change Res., 10(2), 135-141.

Li, Y.P., and Huang, G.H. (2009). Fuzzy-stochastic-based violation analysis method for planning water resources management systems with uncertain information. Inf. Sci., 179(24), 4261-4276. https:// doi.org/10.1016/j.ins.2009.09.001

Li, Y.P., Huang, G.H., Huang, Y.F., and Zhou, H.D. (2009). A multistage fuzzy-stochastic programming model for supporting sustainable water-resources allocation and management. Environ. Model. Software, 24(7), 786-797. https://doi.org/10.1016/j.envsoft. 2008.11.008

Li, Y.P., Huang, G.H., and Nie, S.L. (2010). Planning water resources management systems using a fuzzy-boundary interval-stochastic programming method. Adv. Water Resour., 33(9), 1105-1117. https://doi.org/10.1016/j.advwatres.2010.06.015

Li, Y.P., Huang, G.H., Nie, S.L., and Liu, L. (2008b). Inexact multistage stochastic integer programming for water resources management under uncertainty. J. Environ. Manage., 88(1). 93-107. https://doi.org/10.1016/j.jenvman.2007.01.056

Li, Y.P., Huang, G.H., Yang, Z.F., and Nie, S.L. (2008c). IFMP: Interval-fuzzy multistage programming for water resources management under uncertainty. Resour. Conserv. Recycling, 52(5), 800-812. https://doi.org/10.1016/j.resconrec.2007.11.007

Lian, Y., Gao, C.T., Shen, B.Z., Ren, H.L., Tang, X.L., and Liu, Y.Y. (2007). Climate change and its impact on grain production in Jilin Province. Adv. Clim. Change Res., 3(1), 46-49.

Liu Y.H, Qian F.K., and Wang W.T. (2013). Research of adaptive technology framework of addressing climate change. China Popul. Resour. Environ., 23(5):1-6.

Liu, H.J., and Gao, J.X. (2009). Effects of climate and land use change on the change of NPP in the farming-pastoral ecotone of northern China. Res. Sci., 31 (3), 493-500.

Lu, L., Lin, H.L., and Liu, Q.Y. (2010). Risk map for Dengue fever 
outbreaks based on meteorological factors. Adv. Clim. Change Res., 6(4), 254-258.

Lv, Y., Huang, G.H., Li, Y.P., Yang, Z.F., Liu, Y., and Cheng, G.H. (2010). Planning regional water resources system using an interval fuzzy bi-level programming method. J. Environ. Inf., 16(2), 43-56. https://doi.org/10.3808/jei.201000177

Ma, R.J., and Jiang, Z.G. (2006). Impacts of environmental degradation on wild vertebrates in the Qinghai Lake drainage. China, Acta Ecol. Sin., 26(9), 3061-3066.

Mao, D.H., Song, K.S., Liu, D.W., Zhang, B., Zhang, S.M., Luo, L., and Zhang, C.H. (2011). The vegetation NAVI variation and its response to climate change and LUCC from 1982 to 2006 year northeast permafrost region. China Environ. Sci., 31(2), 283-292.

Margul, S. (2010). The Costs to Developing Countries of Adapting to Climate Change New Methods and Estimates. http://siteresources. worldbank.org

Mastrandrea, M.D., Heller, N.E., Root, T.L., and Schneider, S.H. (2010). Bridging the gap: linking climate-impacts research with adaptation planning and management. Clim. Change, 100(1), 87101. https://doi.org/10.1007/s10584-010-9827-4

Mastrandrea, M., and Field, C. (2010). Guidance note for lead authors of the IPCC fifth assessment report on consistent treatment of uncertainties. Heart Dev., 28(4), 307-329.

MEP (2010). China's biodiversity conservation strategy and action plan (2011-2030). http://www.zhb.gov.cn/gkml/hbb/bwj/201009/ t20100921_194841.htm

Meteorological Administration (2007). Action Plan for implementing National Program on Climate Change. http://www.ccchina.gov.cn/ Detail.aspx?newsId=8444\&TId=57

MOST and ACCA21 (2012). Studies on National Strategy of Climate Change Adaptation, Science Press, Beijing.

MOST (2007). China's Science and Technology Actions on Climate Change. http://www.zhb.gov.cn/gkml/hbb/gwy/200910/W0200711 22477729724814.pdf

MOHC (2007). National environment and health action plan (2007-2015). http://www.gov.cn/zwgk/2007-11/16/content_807439.htm

MOST (2012). National Climate Change Science and technology development plan in 12th Five-Year. http://www.most.gov.cn/tztg/ 201207/t20120711_95481.htm

NARCC EC (2007). National Assessment Report of Climate Change, Science Press, Beijing.

NARCC EC (2011). National Assessment Report of Climate Change (II), Science Press, Beijing.

NARCC EC (2015). National Assessment Report of Climate Change (III), Science Press, Beijing.

NCDR (2011). Guiding opinions of the National Disaster Reduction Committee on strengthening the comprehensive disaster reduction in urban and rural areas. http://www.hbmzt.gov.cn/xxgk/ywb/jzjj/ gzrd/201107/t20110701_101971.shtml

NDRC (2010). Interim Measures for the administration of foreign cooperation in the field of climate change. http://www.mohurd.gov. cn/wjfb/201004/t20100428_200589.html

NDRC (2013). National Strategy for Climate Adaptation. http://www. gov.cn/gzdt/att/att/site1/20131209/001e3741a2cc140f6a8701.pdf

NDRC (2014). National Program on Climate Change (2014-2020), http://www.sdpc.gov.cn/zcfb/zcfbtz/201411/W0201411045847178 07138.pdf

NDRC and MOHURD (2016). Action plan for urban adaptation to climate change. http://www.sdpc.gov.cn/zcfb/zcfbtz/201602/t201 60216_774721.html

Oceanic Administration (2009). Oceanic Program on Climate Change. http://news.xinhuanet.com/2010-09/04/c_12518304_2.htm

Ouyang, L., Dai, S.Z., Bao, C.K., and Wang, X.M. (2010). Study on adapting urban comprehensive disaster prevention plan to climate change. J. Catastrophol., 25(10), 58-62.

Pan, J.H., Zheng, Y., and Markandya, A. (2011). Adaptation approaches to climate change in China: An Operational Framework. Econ. Agr. Recur. Nat., 11(1), 99-112. https://doi.org/10.1142/9789 814578622_0032

Peng Z.G., Lu Q.C. (2012). Adaption Planning for Climatic Change and Extreme Weather Events. Mod. Urban Res., (1), 7-12.

Peng, S.Z., He, X.J., Zhang, J.T., Ma, X., Sun, B., and Liu, S.H. (2015). Current status, problems and recommendations on climate change cdaptation policies in China. China Popul. Resour. Environ., 25(9), 1-7.

Qian, Y.J., Li, S.Z., Wang, Q., Yang, K., Yang, G.J., Lu, S., and Zhou, X.R. (2010). Advances on impact of climate change on human health. Adv. Clim. Change Res., 6(4), 241-247.

Qin, X.S., Huang, G.H., Zeng, G.M., Chakma, A., and Huang, Y.F. (2007) An interval-parameter fuzzy nonlinear optimization model for stream water quality management under uncertainty. Eur. J. Oper. Res., 180(3), 1331-1357. https://doi.org/10.1016/j.ejor.2006. 03.053

Reichler, T., Andrade, M., and Ohara, N. (2014). Use of multi-model ensembles for regional climate downscaling. EGU General Assembly Conference (Vol.16), EGU General Assembly Conference Abstracts.

Ren, G.Y. (2012). Climate change and the engineering projects of the Qinghai-Tibet Plateau. China Eng. Sci., 14(9), 89-95.

Ren, G.Y., Jiang, T., Li, W.J., Zhai, P.M., Luo, Y., and Ma, Z.G. (2008). An integrated assessment of climate change impacts on China's water resources. Adv. Water Sci., 19(6), 772-779.

Schenkel, R. (2010). The challenge of feeding scientific advice into policy-making. Science, 330(6012), 1749-1751. https://doi.org/10. 1126/science. 1197503

Shi, S.Q., Chen, Y.Q., Yao M., Li, Z.B., and He, Y.B. (2002). Impact assessment of cultivated land change upon grain productive capability in Northeast China, Acta Geogr. Sin., 3(6), 574-586.

Shi, X.J., Chen, G.T., and Yu, K.F. (2008). Sea-level change in Zhujiang estuary over last 40 years. Mar. Geol. Quatern. Geol., 28(1), 127-134.

Smit, B. (1993). Adaptation to climatic variability and change. Guelph Environ. Can., 3-17.

Song, L. (2012). Climate risk and adaptation strategies in metropolis dense areas: A case study of Shanghai. China Popul. Resour. Environ., 22(11), 6-12.

State Council (2007). National Program on Climate Change. http://www.cchina.gov.cn/WebSite/CCChina/UpFile/File189.pdf

State Council. (2011). National comprehensive disaster prevention and mitigation plan (2011-2015). http://www.gov.cn/zwgk/201112/08/content_2015178.htm

Sun, Y., Zhang, X.Q., Zheng, D. (2010). The impact of climate warming on agricultural climate resources in the arid region of Northwest China. J. Nat. Resour., 25(7), 1153-1162.

Tang, J., Niu, X., Wang, S., Gao, H., Wang, X., and Wu, J. (2016). Statistical downscaling and dynamical downscaling of regional climate in china: present climate evaluations and future climate projections. J. Geophys. Res. Atmos., 121(5). https://doi.org/10. 1002/2015JD023977

Tao, F., Zhang, S., and Zhang, Z. (2012). Spatiotemporal changes of wheat phenology in China under the effects of temperature, day length and cultivar thermal characteristics. Eur. J. Agron., 43, 201-212. https://doi.org/10.1016/j.eja.2012.07.005

The Administrative Center for China's Agenda 21(ACCA21). (2017). Study on Climate Change Adaptation Strategy of Scientific and Technological Development in China, Science Press, Beijing.

United Nations Framework Convention on Climate Change (UN- 
FCCC) (2015). Adaption of the Parisagreement. http://unfccc.int/ files/essential_background/convention/application/pdf/english_par is_agreement.pdf

Wang, X.Q., Huang, G.H., Lin, Q.G., and Liu, J.L. (2014). Highresolution probabilistic projections of temperature changes over Ontario, Canada. J. Clim., 27(14), 5259-5284. https://doi.org/ 10.1175/JCLI-D-13-00717.1

Wang, X.Q., Huang, G.H., Lin, Q.G., Nie, X.G., and Liu, J.L. (2015). High-resolution temperature and precipitation projections over Ontario, Canada: A coupled dynamical-statistical approach. Q. J. R. Meteorol. Soc., 141(689), 1137-1146. https://doi.org/10.1002/qj. 2421

Wang, Y., and Peng, S.M. (2016). Drought monitoring and water resources allocation technology framework of yellow river basin. Yellow River, 38(10), 88-92.

Wu, C, Hu, S.J, and Zhao, C.Y. (2016). Dynamic of soil moisture and water consumption of cotton under drip irrigation patterns in tarim irrigation area. Water Sav. Irrig., 2, 14-17.

Wu, J.G., Zhou, Q.F., and Li,Y. (2011). Strategies of adaptation to climate change for biodiversity in China. China Popul. Res. Environ., 21(3), 435-439.

Wu, S.H., Huang, J.K., and Liu, Y.H. (2014). Pros and cons of climate change in China. China Popul. Res. Environ., 24(1), 7-13. https://doi.org/10.1080/10042857.2014.910878

Xie, L.Y., Li, Y., and Lin, M. (2011). Response and adaptation to climate change of agriculture and environment in Northeast China. Chin. J. Eco-Agric., 19(1), 197-201. https://doi.org/10.3724/SP.J. 1011.2011.00197

Yang, G.J., Yan, K., and Zhou, X.N. (2010a). Assessment models for impact of climate change on vector-vorne diseases transmission. Adv. Clim. Change Res., 6(4), 259-264.

Yang, K., Pan, J., Yang G., Li, S.Z, Xu, Y.L., and Zhou, X.N. (2010b).
Projection of the transmission scale and intensity of schistosomiasis in China under A2 and B2 climate change scenarios. Adv. Clim. Change Res., 6 (4), 248-253.

Yuan, J.W., Ni, J. (2007). Plant signals and ecological evidences of climate change in China, Arid Land Geogr., 30(4), 465-473.

Zhang, D.Q., and Qian, Z.H. (2008). Analysis of extreme events in China's temperature in recent 50 years using detecting method based on median. Acta Phys Sin., 57(7), 6435-6440.

Zhang, J.Y., Zhang, S.L., Wang, J.X., and Li, Y. (2007). Study on runoff trends of the six large basins in China over the past 50 years. Adv. Water Sci., 18(2), 230-234.

Zhang, S.Q., Pu, Z.C., Fu, X.H., and Ding, L. (2010). The influence of climate change on NPP in Xinjiang. Arid Zone Res., 27(6), 905-914.

Zhang, T.Y. (2010). Policies and actions for adaptation to climate change in China marine area, Mar. Forecasts, 27(4), 67-73.

Zhang, X.Y., He, X.J., and Sun, B. (2015). Assessment on climate change adaptation policies in China. China Popul. Res. Environ., 25(9), 45-48.

Zhao, H.Y. (2007). Recent 45 years climate change and its effects on ecological environment on Hulunbeier sandy land. Chin. J. Ecol., 26(11), 1817-1821.

Zhao, J.F., Guo, J.P., Zhang, Y.H., and Xu, J.W. (2010). Advances in research of impacts of climate change on agriculture, Chin. J. Agrometeorol., 31(2), 200-205.

Zhou, X.N., Guo, J.G., and Wu, Q.W. et al. (2007). Epidemiology of schistosomiasis in the People's Republic of China. 2004. Emerging Infect. Dis., 13(10), 1470-1476. https://doi.org/10.3201/eid1310. 061423

Zhou, S.D., and Zhu, H.G. (2010). Economic analysis of climate change impact on the rice yield in Southern China and its adaptive strategy. China Popul. Res. Environ., 20(10), 152-157. 